\title{
THÀNH LẬP BẢN ĐỔ HỆ THỐNG SỬ DỤ̂NG ĐÂT NÔNG NGHIỆP HUYỆN PHÙ MỸ, TỈNH BİNH ĐỊNH THEO TIẾP CẬN CẢNH QUAN ĐỊA MẠO-THỔ NHƯỠNG
}

\author{
NGUYẼ̃N TRỌNG ĐợI ${ }^{1}$, NGUYẼ̃N CAO HUẦ ${ }^{2}$, TRẦN VĂN TUẤN ${ }^{2}$ \\ ${ }^{\prime}$ Khoa Khoa hoc Tư nhiên-Truoòng Đại hoc Quy Nhon, \\ ${ }^{2}$ Khoa Địa lý-Truòng Đại học Khoa học Tụ nhiên-Đại học Quốc gia Hà Nội
}

\section{Tóm tắt:}

Đơn vị đất đai vẫn được xem là đối tương co bản nhất trong đánh giá đất đai để chỉ ra sụ thich nghi của các loại sử dụng đất trong sản xuất nông nghiệp. Tuy nhiên, việc đánh giá dựa trên đơn vị đất đai chura đánh giá tổng hợp được các yếu tố kinh tế-xã hội và môi truờng cũng nhu việc giải quyết bài toán đánh giá đa quy mô lãnh thổ. Nghiên cưu này dựa trên tiếp cận cảnh quan địa mạothổ nhwỡng là huớng nghiên cứu mới để xác định các chỉ tiêu xây dựng, phân cấp đơn vị đất đai và phân loại sử dụng đất, tù̀ đó thành lập bản đồ hệ thống sủ dụng đất nông nghiệp cho huyện Phù Mỹ, tỉnh Bình Định. Hệ thống sủ dụng đất thể hiện được mối quan hệ theo cấu trúc đứng của cảnh quan địa lý của các nhân tố cấu thành và sẽ được sử dụng là đơn vị đánh giá sụ thích hợp của loại sủ dụng đất trong hệ thống sư dụng đất đó.

\section{1. ĐẶT VẤN ĐỀ}

Hệ thống sử dụng đất (Land Use SystemLUS) là sự kết hợp của loại sử dụng đất (SDĐ) với điều kiện đất đai tạo thành hai hợp phần tác động lẫn nhau, từ tương tác này sẽ quyết định các đặc trưng về mức độ và các loại chi phí đầu tư, mức độ và loại cải tạo đất đai và năng suất, sản lượng của loại SDĐ [1]. Các nghiên cứu về LUS được thực hiện từ rất sớm ở các nước châu Âu, được xác định là đơn vị cơ bản trong phân vùng sinh thái nông nghiệp [2], [3], phân tích LUS được xem là công cụ quan trọng trong quy hoạch SDĐ, phục vụ quản lý đất đai bền vững [4]. Tuy nhiên trên thực tế những nghiên cứu và ứng dụng về LUS trong đánh giá thích nghi đất đai lại rất ít, thậm chí trong các công bố của FAO chủ yếu dựa trên đơn vị đất đai (ĐVĐĐ) thuần túy để đánh giá.

Hầu hết các nghiên cứu đều chung quan điểm, cho rằng LUS là sự kết hợp giữa đơn vị đất đai (Land Mapping Unit) và loại sử dụng đất (Land Use Type). LUS = LMU + LUT [5], theo FAO ĐVĐĐ là một vùng đất/khoanh đất được xác định ngoài thực địa hoặc trên bản đồ với các đặc điểm cụ thể [6], việc xác định ĐVĐĐ dựa trên các đặc tính, tính chất vốn có của đất đai và có thể phân biệt được chúng trên bản đồ ĐVĐĐ. Loại SDĐ là các loại cây trồng được xác định và lựa chọn đưa vào canh tác trên cơ sở đánh giá thích nghi đất đai hoặc theo nhu cầu của người SDĐ. Đánh giá đất đai theo FAO được áp dụng rộng rãi và được hiểu là quá trình so sánh, đối chiếu nhu cầu sinh thái của loại cây trồng với các tính chất của ĐVĐĐ [6]. Do đó, đánh giá đất chỉ dựa trên ĐVĐĐ là chưa toàn diện, chủ yếu là các chỉ tiêu tự nhiên gắn liền với đất, mà chưa phản ánh hết các yếu tố kinh tế-xã hội và môi trường của quá trình SDĐ.

Ở Việt Nam, trong những năm gần đây cũng có những công trình nghiên cứu về LUS như đánh giá LUS đai phục vụ quy hoạch SDĐ nông nghiệp bền vững [7], đánh giá LUS đai phục vụ phát triển nông nghiệp bền vững [8]. Tuy nhiên, những nghiên cứu này việc đánh giá các LUS vẫn dựa trên đặc điểm của ĐVĐĐ. Ở một hướng nghiên cứu khác, đánh giá tổng hợp hiệu quả kinh tế sinh thái cho cây lúa [9] cũng dựa trên bản đồ ĐVĐĐ, tuy nhiên yếu tố địa mạo đã được xem xét là một trong các yếu tố cấu thành 
ĐVĐĐ và là chỉ tiêu để đánh giá mức độ thích nghi.

Tiếp cận trên phương diện cảnh quan gắn với đất đai, cảnh quan địa mạo-thổ nhưỡng (ĐM$\mathrm{TN})$ là một bộ phận của cảnh quan địa lý, được định nghĩa là là một hệ thống đất được kết cấu bởi các hợp phần đất lặp lại theo những trật tự xác định, liên quan với đặc điểm địa hình và có quan hệ tương quan giữa các hợp phần tạo thành một tổng thể thống nhất [11]. Cảnh quan ĐM$\mathrm{TN}$ đã được xem xét là đơn vị tương đương với cảnh quan đất trong điều tra đất, sự kết hợp tiêu chí địa mạo và thổ nhưỡng để thiết lập bản đồ đơn vị đất và phân tích sự phân bố đất trong cảnh quan [10]. Ở nước ta, hướng nghiên cứu về cảnh quan ĐM-TN cũng là khá mới mẻ, ĐM-TN được nghiên cứu cho quy hoạch phát triển kinh tế [11], cho quy hoạch SDĐ [12], cho sử dụng bền vững tài nguyên đất Việt Nam [13] và cho đánh giá thích nghi sinh thái [14].

Nghiên cứu thành lập bản đồ LUS huyện Phù Mỹ, tỉnh Bình Định dựa trên tiếp cận cảnh quan ĐM-TN sẽ xây dựng các chỉ tiêu thành lập và phân cấp ĐVĐĐ dựa trên các chỉ tiêu của quá trình địa mạo và đặc điểm thổ nhưỡng khu vực nghiên cứu. Cùng với nghiên cứu đặc điểm của quá trình $\mathrm{SDĐ}$ của các loại SDĐ, phân cấp loại SDĐ theo các mức độ từ chi tiết đến khái quát hóa. Tổ hợp phân cấp ĐVĐĐ và phân cấp loại SDĐ tổ hợp thành các LUS với sự phân cấp khác nhau ứng với cấp lãnh thổ trong nghiên cứu.

\section{PHƯƠNG PHÁP LUẬN}

\subsection{Cách tiếp cận}

Mỗi vùng lãnh thổ khác nhau có những đặc điểm khác nhau về điều kiện tự nhiên và quá trình khai thác sử dụng lãnh thổ. Nghiên cứu, đánh giá lãnh thổ dựa trên cảnh quan ĐM-TN, vùng nghiên cứu sẽ được phân chia theo các cấp phân vị cảnh quan ĐM-TN khác nhau tương tự trong phân cấp cảnh quan địa lý chung. Từ phân cấp cảnh quan, sẽ xác định được đối tượng địa lý cụ thể theo mục tiêu đánh giá. Do đó, dựa trên tiếp cận cảnh quan trong xây dựng bản đồ LUS cần phải nghiên cứu, phân cấp ĐVĐĐ và phân loại SDĐ cũng như trong tổng hợp tạo thành phân loại LUS.

Quy mô lãnh thổ, sự đồng nhất của các yếu tố được xem xét khi xây dựng bản đồ ĐVĐĐ, là cơ sở để lựa chọn và phân cấp các chỉ tiêu xây dựng bản đồ đất đai. Trên nền chung về điều kiện nhiệt ẩm của lãnh thổ, các ĐVĐĐ được phân chia chủ yếu dựa vào tiêu chí về nền tảng rắn, dinh dưỡng đất (Địa hình và thổ nhưỡng) và các yếu tố liên quan tới khả năng tưới tiêu trong canh tác. Đơn vị đất đai được xác định dựa trên tổ hợp của các bản đồ đơn tính thành phần, xuất phát từ các chỉ tiêu của cảnh quan ĐM-TN và được phân chia thành 3 cấp. Đơn vị đất đai cấp 1 thể hiện mức độ khái quát nhất về các yếu tố thành tạo đơn vị bản đồ đất đai bao gồm địa mạo và nhóm đất. Đơn vị đất đai cấp 2 thể hiện chỉ tiêu về địa mạo và mức độ chi tiết hơn của thổ nhưỡng là loại đất. Đơn vị đất đai cấp 3 là những chỉ tiêu thể hiện mức độ chi tiết của thổ nhưỡng như loại đất, độ dốc, tầng dày, thành phần cơ giới. Ở phân cấp này các chỉ tiêu của ĐVĐĐ gần như trùng với các chỉ tiêu trong nghiên cứu cảnh quan ĐMTN. Đơn vị đất đai cấp 4 là phân cấp chi tiết nhất hơn với khả năng tưới tiêu.

Phân loại SDĐ nông nghiệp cũng được phân loại theo mức độ khái quát đến chi tiết theo phân loại sử dụng của ngành tài nguyên môi trường và được phân loại theo 4 cấp. Kiểu sử dụng đất là đơn vị cao nhất của SDĐ nông nghiệp được phân chia dựa theo tiêu chí mục đích sử dụng chính, bao gồm kiểu SDĐ sản xuất nông nghiệp, kiểu SDĐ lâm nghiệp, kiểu SDĐ nuôi trồng thủy sản, kiểu SDĐ làm muối và kiểu SDĐ nông nghiệp khác. Phu kiểu sư dụng đất là đơn vị thứ cấp của kiểu SDĐ được phân chia dựa theo tiêu thời gian sinh trưởng hoặc tính chất của kiểu SDĐ, chẳng hạn kiểu SDĐ sản xuất nông nghiệp gồm phụ kiểu SDĐ cây hàng năm và phụ kiểu $\mathrm{SDĐ}$ cây lâu năm; Kiểu SDĐ lâm nghiệp gồm phụ kiểu đất rừng sản xuất, phụ kiểu đất rừng phòng hộ và phụ kiểu đất rừng đặc dụng. Loại sư dụng đất là đơn vị cơ bản của SDĐ nông nghiệp, được xác định dựa trên mức độ chi tiết của các dấu hiệu phụ kiểu. Chẳng hạn, phụ kiểu SDĐ cây hàng 
năm bao gồm loại SDĐ chuyên trồng trồng lúa nước, loại SDĐ hoa màu, loại SDĐ lúa màu; Phụ kiểu SDĐ cây lâu năm bao gồm loại SDĐ cây công nghiệp lâu năm và loại SDĐ cây ăn quả lâu năm. Phu loại sủ dụng đất là đơn vị cấp nhỏ nhỏ nhất của SDĐ nông nghiệp, được xác định từ sự phân chia của loại SDĐ theo mùa vụ, loại cây trồng cụ thể hoặc kỹ thuật canh tác tùy thuộc vào dấu hiệu của từng loại $\mathrm{SDĐ}$. Chẳng hạn, phụ loại sử dụng chuyên trồng lúa nước vụ Đông Xuân, phụ loại SDĐ trồng ngô vụ Xuân Hè, phụ loại SDĐ trồng keo lai, ...

Từ phân loại của SDĐ nông nghiệp kết hợp với phân cấp của ĐVĐĐ tổ hợp thành phân cấp LUS, kết quả nghiên cứu tổ hợp tại Bảng 1. Từ sự phân cấp này sẽ xác định được loại bản đồ LUS cần thành lập tương ứng với mục tiêu và quy mô lãnh thổ nghiên cứu. (Xem bảng 1)

\subsection{Quy trình và phương pháp nghiên cúu}

\subsubsection{Quy trình nghiên cúu}

\section{(Xem hinh 1)}

Quy trình thành lập bản đồ LUS nông nghiệp bao gồm 4 bước.

Bước 1. Thu thập số liệu, tài liệu, bản đồ. Tiến hành thu thập các loại số liệu niên giám thống kê về kinh tế-xã hội, tình hình sản xuất nông nhiệp, các số liệu khí tượng thủy văn, các tài liệu về điều kiện tự nhiên, tài nguyên thiên nhiên đặc biệt là các loại bản đồ như bản đồ đất, bản đồ địa hình, bản đồ địa chất và bản đồ hiện trạng sử dụng đất. Bên cạnh đó, trong nghiên cứu này trên địa bàn huyện Phù Mỹ, tỉnh Bình Định còn đào 7 phẩu diện đất, phân tích mẫu để cập nhật cho bản đồ đất.

Buớc 2. Chuẩn hóa dũ liệu thu thập, xác định các chì tiêu ĐVĐĐ và phân loại SDĐ: Chuẩn hóa các dữ liệu bản đồ về định dạng *.shp, chuẩn hóa dữ liệu về hệ tọa độ VN2000 để thuận tiện trong phân tích không gian. Phân tích các tài liệu về khu vực nghiên cứu để xác định các chỉ tiêu ĐVĐĐ và phân loại $\mathrm{SDĐ}$. Các chỉ tiêu ĐVĐĐ bao gồm nhóm Địa hình, địa mạo (địa mạo, đá mẹ/tuổi địa chất); nhóm thổ nhưỡng (nhóm đất/loại đất, thành phần cơ giới, tầng dày, độ dốc); nhóm thủy lợi-thủy nông (khả năng tưới, khả năng tiêu). Căn cứ vào hiện trạng của huyện Phù Mỹ, các loại SDĐ nông nghiệp được xác định và phân thành kiểu SDĐ, phụ kiểu $\mathrm{SD}$, loại $\mathrm{SD}$ và phụ loại $\mathrm{SD}$.

Bước 3. Xây dưng các lớp dũ liệu đơn tính: Xây dựng các lớp chuyên đề theo các chỉ tiêu của bản đồ ĐVĐĐ, dữ liệu hiện trạng SDĐ được phân thành các lớp kiểu SDĐ, phụ kiểu SDĐ, loại $\mathrm{SD}$ và phụ loại $\mathrm{SD}$.

Bước 4. Thành lập bản đồ ĐVĐĐ và bản đồ LUS: Tùy theo mục tiêu thành lập bản đồ và quy mô lãnh thổ để chọn các chỉ tiêu thành lập bản đồ ĐVĐĐ (cấp 1, 2, 3), phân loại SDĐ để tổ hợp thành bản đồ LUS.

\subsubsection{Phwơng pháp thu thập, xủ lý số liệu, tài} liệu.

Thu thập các nguồn số liệu, tài liệu có liên quan đến khí hậu, thủy văn, dữ liệu các hồ chứa và các thông tin về tình hình sản xuất nông nghiệp của khu vực nghiên cứu để phục vụ xác định các chỉ tiêu ĐVĐĐ và phân loại SDĐ. Thu thập dữ liệu bản đồ đất, bản đồ địa chất, địa hình và hiện trạng $\mathrm{SDĐ}$, sau đó chuẩn hóa định dạng dữ liệu thống nhất về *.shp và hệ thọa độ VN2000.

\subsubsection{Phuoong pháp khảo sát thực địa}

Phương pháp này được sử dụng để xác định các loại SDĐ trên thực tế, xác định và làm rõ sự

Bảng 1: Tổng hợp phân loại hệ thống sủ dụng đất

\begin{tabular}{|c|c|c|c|c|c|c|}
\hline$T T$ & Phân loai LUS & $=$ & Phân loai $\boxplus V \boxplus \boxplus$ & + & Phân loai $S D \oplus$ & Cấp lãnh thế \\
\hline 1 & Kiểu LUS & $=$ & ĐVĐĐ cấp 1 & + & Kiể SDĐ & Vùng, cả nước \\
\hline 2 & Phụ kiểu LUS & $=$ & ĐVĐĐ cấp 2 & + & Phụ kiểu SDĐ & Tinh \\
\hline 3 & Loại LUS & $=$ & ĐVĐĐ cấp 3 & + & Loại SDĐ & Huyện \\
\hline 4 & Phụ loại LUS & $=$ & ĐVĐĐ cấp 4 & + & Phụ loại SDĐ & $\mathrm{X}$ ã/vùng canh tác \\
\hline
\end{tabular}


Hình 1: Quy trình thành lập bản đồ hệ thống sủ dụng đất nông nghiệp

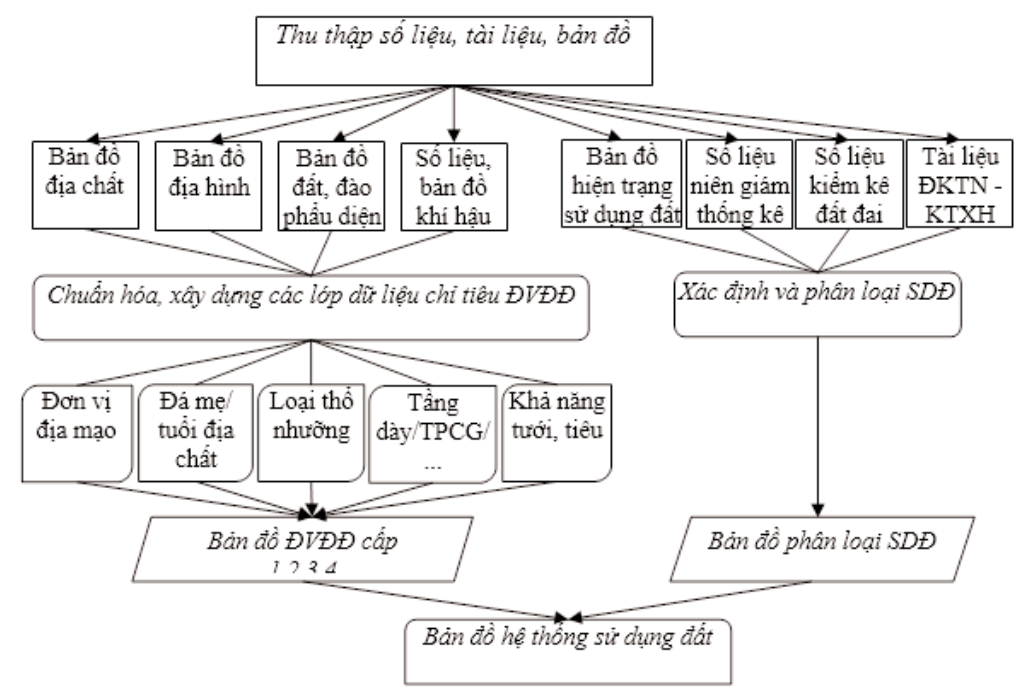

phân hóa các điều kiện tự nhiên lãnh thổ nghiên cứu, đồng thời đào các phẫu diện đất bổ sung để cập nhật bản đồ đất. Khảo sát thực địa còn là công việc quan trọng để kiểm chứng kết quả xử lý dữ liệu và thành lập bản đồ ĐVĐĐ và bản đồ LUS.

\subsubsection{Phương pháp bản đồ và GIS}

Sử dụng các phần mềm như MicroStation, Mapinfo và Arcgis để chuẩn hóa dữ liệu, thành lập các lớp bản đồ chuyên đề thể hiện các chỉ tiêu của ĐVĐĐ như địa mạo, loại đất, độ dốc, thành phần cơ giới, ... Thành lập bản đồ ĐVĐĐ, bản đồ LUS nông nghiệp huyện Phù Mỹ, tỉnh Bình Định.

\subsection{Dũ liệu}

Nghiên cứu sử dụng các dữ liệu bản đồ theo hệ tọa độ Quốc gia VN2000 các loại bản đồ tại bảng 2 , số liệu niên giám thống kê và dữ liệu thống kê, kiểm kê đất đai từ năm từ năm 2014 đến năm 2020 từ Chi cục Thống kê và Phòng Tài nguyên và Môi trường huyện Phù Mỹ. Ngoài ra còn tham khảo số liệu tài liệu từ các quy hoạch, kế hoạch SDĐ, quy hoạch tổng thể phát triển kinh tế xã hội và Tiêu chuẩn Việt Nam 8409:2012 "Quy trình đánh giá đất nông nghiệp". Bên cạnh đó còn tiến hành đào và phân tích 14 mẫu đất để thành lập bản đồ đất đai

huyện Phù Mỹ tỉ lệ 1:25.000. (Xem bảng 2)

\section{KẾT QUẢ NGHIÊN CỨU VÀ THẢO LUẬN}

\subsection{Khái quát về khu vục nghiên cứu}

Phù Mỹ là một huyện ven của tỉnh Bình Định (tọa độ $14^{\circ} 04^{\prime} 23^{\prime}$ '-14 $23^{\prime} 00^{\prime}$ vĩ Bắc, 10856'00"-109 13 '00" kinh Đông) với đường bờ biển dài $34 \mathrm{~km}$, có sự đa dạng, đan xen về kiểu địa hình từ Tây sang Đông. Ở phía Tây, Tây Bắc và vùng Trung tâm là các đồi núi thấp có cao độ từ $450 \mathrm{~m}-650 \mathrm{~m}$, ở phía Đông là đồng bằng nhỏ, độ cao từ $6 \mathrm{~m}-20 \mathrm{~m}$ và vùng ven biển cao độ chỉ từ $2 \mathrm{~m}-3 \mathrm{~m}$. Kết quả nghiên cứu địa chất địa mạo cho thấy, lãnh thổ huyện Phù Mỹ có 16 đơn vị địa mạo, trong đó các đơn vị địa mạo có nguồn gốc biển chiếm ưu thế và nguồn gốc do quá trình bóc mòn tổng hợp chiếm hầu hết diện tích lãnh thổ. Do phát sinh trên nền đá trầm tích - biến chất và đá trầm tích Đệ tứ không phân chia, thổ nhưỡng Phù Mỹ mang đặc trưng của 07 nhóm (đất đỏ vàng, đất dốc tụ, đất phù sa, đất xám và bạc màu, đất mặn, đất cát và cồn cát ven biển, đất xói mòn trơ sỏi đá). Khu vực có 2 đầm lớn Đề Gi và Trà Ổ với các hệ sinh thái đặc thù, chiếm phần lớn diện tích của lưu vực sông La Tinh là điều kiện thuận lợi cho huyện Phù Mỹ phát triển nền kinh tế nông nghiệp đa dạng và 
Bảng 2: Dũ liệu các loại bản đồ thu thập phục vu nghiên cưu

\begin{tabular}{|c|l|c|c|l|}
\hline$T T$ & \multicolumn{1}{|c|}{ Loại bản đồ } & Ti lệ & Định dang & \multicolumn{1}{|c|}{ Nguồn } \\
\hline 1 & $\begin{array}{l}\text { Bản đồ hiện trạng SDĐ huyện } \\
\text { Phù Mỹ } 2014,2019\end{array}$ & $1: 25.000$ & $\begin{array}{l}\text { MicroStation } \\
\text { (*.dgn) }\end{array}$ & Sờ TNMT Bình Định \\
\hline 2 & Bản đồ địa hình huyện Phù Mỹ & $1: 10.000$ & $\begin{array}{l}\text { MicroStation } \\
\text { (*.dgn) }\end{array}$ & Sở TNMT Bình Định \\
\hline 3 & $\begin{array}{l}\text { Bản đồ đất tỉnh Bình Định năm } \\
2005\end{array}$ & $1: 100.000$ & Mapinfo (*.tab) & $\begin{array}{l}\text { Sờ NN\&PTNT Bình } \\
\text { Định }\end{array}$ \\
\hline 4 & Bản đồ địa chất tỉnh Bình Định & $1: 50.000$ & Mapinfo (*.tab) & $\begin{array}{l}\text { Liên đoàn Địa chất } \\
\text { Trung Trung Bộ }\end{array}$ \\
\hline
\end{tabular}

phong phú.

\subsection{Kết quả thành lập bản đồ hệ thống sủ dụng đất huyện Phù Mỹ, tỉnh Bình Định}

\subsubsection{Kết quả thành lập bản đồ đonn vị đất đai}

Trên cơ sở chuẩn hóa dữ liệu các loại bản đồ thu thập được và phân tích đặc điểm tự nhiên huyện Phù Mỹ đã xác định được các chỉ tiêu, nhóm chỉ tiêu xây dựng bản đồ ĐVĐĐ. Mỗi chỉ tiêu được xây dựng thành lớp chuyên đề để tổ hợp thành các bản đồ ĐVĐĐ cấp $1,2,3$ và 4 . Kết quả chồng xếp các bản đồ đơn tính bằng công cụ GIS xây dựng được bản đồ ĐVĐĐ cấp 1,2 và 3 tương ứng với $37 \mathrm{ĐVĐĐ} \mathrm{cấp} 1,43$ ĐVĐĐ cấp 2, 84 ĐVĐĐ cấp 3 và 96 ĐVĐĐ cấp 4

Phân tích bản đồ ĐVĐĐ cấp 3 (Hình 2), cho thấy số lượng và diện tích các ĐVĐĐ tập trung nhiều ở kiểu địa mạo Thềm mài mòn bậc III, với 22 đơn vị và tổng diện tích là $13.358,19$ ha. Ít nhất là trên kiểu địa mạo bãi biển mài mòn, chỉ có 1 đơn vị 16,61 ha. Về đặc điểm phân bố theo lãnh thổ, do sự phân hóa về địa hình thấp dần từ Tây sang Đông nên các ĐVĐĐ cũng phân hóa chung theo các đơn vị địa mạo. Các ĐVĐĐ trên bề mặt san bằng -> các ĐVĐĐ trên các bề mặt sườn -> các ĐVĐĐ trên các thềm mài mòn, thềm tích tụ và đến các ĐVĐĐ trên các trảng cát, đụn cát ven biển, các bãi biển.

Các yếu tố trên mỗi đơn vị đất đai thể hiện được quá trình hình thành và phát triển của kiểu đơn vị đất đai: Địa chất, quá trình địa mạo và các tính chất hóa lý của đơn vị đất đai như tầng dày, độ dốc, thành phần cơ giới, ... (Xem hình 2)

3.2.2. Kết quả thành lập bản đồ hệ thống sủ dụng đất
Qua phân tích số liệu niên giám thống kê, dữ liệu hiện trạng SDĐ huyện Phù Mỹ, SDĐ nông nghiệp của vùng nghiên cứu được xác định và phân loại gồm 5 kiểu SDĐ, 6 phụ kiểu SDĐ và 7 loại SDĐ. Huyện Phù Mỹ có tổng diện tích đất nông nghiệp là 44.467,6 ha, chiếm 80,0\% tổng diện tích đất tự nhiên. Trong 5 kiểu SDĐ, kiểu SDĐ sản xuất nông nghiệp và kiểu SDĐ lâm nghiệp là 2 kiểu sử dụng đất chính với 43.582,3 ha chiếm 78,4\%. Ở cấp phân loại phụ kiểu SDĐ, phụ kiểu SDĐ cây hàng năm có diện tích lớn nhất $18.712,0$ ha chiếm $42,08 \%$ diện tích đất nông nghiệp. Đối với cấp loại SDĐ, loại SDĐ chiếm ưu thế nhất trong kiểu SDĐ sản xuất nông nghiệp là loại SDĐ hoa màu và chuyên trồng lúa với diện tích lần lượt là 9.836,0 ha (chiếm $22,1 \%$ ) và $7.750,6$ ha (chiếm $17,4 \%$ ).

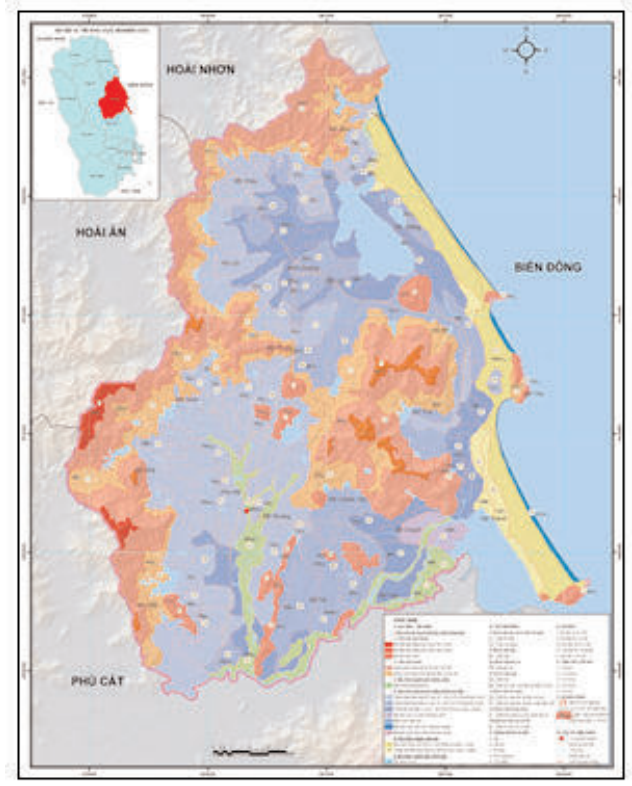

Hình 2: Bản đồ đơn vị đất đai cấp 3 huyện Phù Mỹ, tỉnh Bình Định 
Theo hệ thống phân loại LUS đã được xây dựng thể hiện mức độ chi tiết của các loại SDĐ nông nghiệp được phân loại và ĐVĐĐ đã được phân cấp. Với quy mô lãnh thổ cấp huyện, bản đồ LUS huyện Phù Mỹ được xác định xây dựng ở mức "Loại LUS". Do vậy, tiến hành tổ hợp bản đồ loại SDĐ nông nghiệp (7 loại) với bản đồ ĐVĐĐ cấp 3 (84 ĐVĐĐ) được bản đồ LUS nông nghiệp huyện Phù Mỹ (Hình 3) với 174 LUS nông nghiệp. Trường hợp nghiên cứu cho cấp xã và vùng canh tác sẽ phải xây dựng bản đồ LUS chi tiết ở cấp phụ loại LUS từ sự tổ hợp của ĐVĐĐ cấp 4 với phụ loại SDĐ. Bản đồ phụ LUS ở cấp phụ loại LUS sẽ phản ánh đầy đủ nhất các đặc điểm của LUS theo mùa vụ và là phân cấp đơn vị tốt nhất để đánh giá LUS về mọi mặt.

Bản đồ LUS thực chất là sự phân chia của bản đồ hiện trạng sử dụng đất dựa trên nền bản đồ đơn vị đất đai, số khoanh vi trên bản đồ LUS phụ thuộc vào mục tiêu nghiên cứu ứng với cấp lãnh thồ, từ đó lựa chọn và tổ hợp phân loại SDĐ và phân cấp ĐVĐĐ phù hợp.

Kết quả thống kê từ bản đồ LUS nông nghiệp huyện Phù Mỹ cho thấy, hệ thống sử dụng đất rừng phòng hộ và rừng sản xuất chỉ có 11 khoanh vị nhưng chiếm $49 \%$ diện tích các LUS nông nghiệp. Hệ thống các LUS phân bố chủ yếu trên các bề mặt bóc mòn tổng hợp có các loại thổ nhưỡng chính là đất feralit vàng đỏ trên đá macma axit và đất feralit đỏ vàng trên đá phiến và đá sét biến chất.

Trong phụ kiểu LUS cây hàng năm, các LUS chuyên trồng lúa huyện Phù Mỹ chiếm diện tích lớn nhất với 46 LUS, chiếm $20 \%$ tổng diện tích LUS nông nghiệp. Các LUS chuyên trồng lúa phân bố chủ yếu trên các kiểu địa mạo thềm mài mòn tích tụ bậc II, III và đáy thung lũng tích tụ với địa hình bằng phẳng, các loại thổ nhưỡng chính là đất phù sa, đát xám trên phù sa cổ và đất thung lũng dốc tụ. Cùng trên kiểu địa mạo và điều kiện đất đai này là các LUS lúa-màu (23 LUS). Các LUS trồng cây hoa màu có số lượng lớn nhất 96 LUS, chiếm 16\% diện tích các LUS nông nghiệp, được phân bố xen kẽ với các LUS chuyên trồng lúa và lúa-màu, phổ biến ở các
ĐVĐĐ có loại thổ nhưỡng là đất xám trên phù sa cổ, đất xám bạc màu, đất phù sa và feralit.

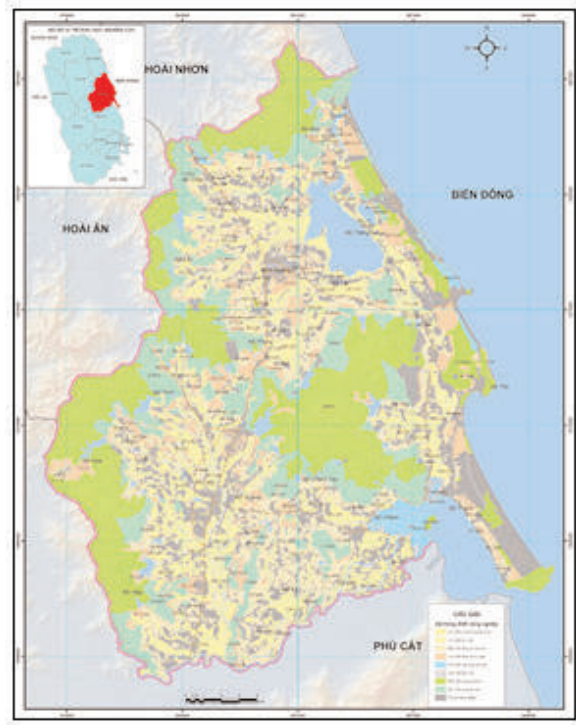

Hình 3: Bản đồ hệ thống sủ dụng đất nông nghiệp huyện Phù Mỹ

Các LUS cây lâu năm chiếm diện tích khoảng $10 \%$ các LUS nông nghiệp, với số lượng 42 LUS được phân bố trên các kiểu địa mạo thềm mài mòn tích tụ bậc II, III với các loại thổ nhưỡng đất feralit, đất xám và trên kiểu địa mạo đụn cát tích tụ với loại thổ nhưỡng chính là đất cồn cát ven biển.

Các LUS nuôi trồng thủy sản và LUS làm muối chỉ chiếm khoảng $2 \%$ diện tích, phân bố tập trung trên kiểu địa mạo đụn cát tích tụ và bãi biển tích tụ với loại thổ nhưỡng chính là đất mặn và đất cồn cát ven biển.

\subsection{Thảo luận}

Cảnh quan học nghiên cứu lãnh thổ theo cả cấu trúc ngang và cấu trúc đứng để làm rõ tính quy luật của các đối tượng địa lý. Tiếp cận cảnh quan ĐM-TN trong thành lập bản đồ LUS là hướng nghiên cứu cho thấy mối quan hệ các chỉ tiêu xây dựng bản đồ ĐVĐĐ không thể nằm ngoài quy luật của địa lý, loại SDĐ nông nghiệp thể hiện trạng thái tác động của con người lên ĐVĐĐ để tạo thành LUS sẽ được đánh giá thích hợp một cách đầy đủ và có hệ thống. 
Đánh giá hiệu quả sản xuất nông nghiệp dựa trên đánh giá thích nghi đất đai hoặc đánh giá kinh tế sinh thái các LUS dựa trên nền ĐVĐĐ theo các loại SDĐ. Để đánh giá phù hợp với mục tiêu và quy mô lãnh thổ cần phải phân cấp ĐVĐĐ phù hợp với lãnh thổ nghiên cứu, phân loại SDĐ phù hợp với yêu cầu của quản lý nhà nước về đất đai. Do vậy, dựa trên phân cấp ĐVĐĐ và phân loại SDĐ, mối quan hệ giữa quy mô lãnh thổ, mục tiêu nghiên cứu và việc lựa chọn các chỉ tiêu nghiên cứu được rõ ràng và mang tính hợp lý hơn.

Các LUS nông nghiệp không chỉ khác biệt dựa trên điều kiện đất đai và loại SDĐ mà còn ở trình độ canh tác trên mỗi hệ thống được phản ánh thông qua các điều kiện về kinh tế-xã hội. Chỉ ra sự khác biệt về mặt kinh tế-xã hội trên mỗi LUS sẽ làm sáng tỏ hơn sự khác biệt của các LUS và cần được sử dụng để đánh giá hiệu quả kinh tế sinh thái LUS.

\section{KẾT LUẬN}

Dựa trên tiếp cận cảnh quan ĐM-TN đã xác định được các chỉ tiêu, phân cấp chỉ tiêu xây dựng ĐVĐĐ và phân loại SDĐ để xây dựng bản đồ LUS cho đa quy mô lãnh thổ và thể hiện được mối quan hệ chặt chẽ của các yếu tố trong LUS.

Bản đồ ĐVĐĐ huyện Phù Mỹ được tổ hợp từ các nhóm chỉ tiêu địa mạo, thổ nhưỡng. Kết quả thu được 37 ĐVĐĐ cấp 1, 43 ĐVĐĐ cấp 2, 84 ĐVĐĐ cấp 3 và 96 ĐVĐĐ cấp 4 . Tổ hợp bản đồ ĐVĐĐ cấp 3 và bản đồ loại SDĐ nông nghiệp có được bản đồ LUS ở phân cấp loại SDĐ với 174 LUS.

Thống kê, phân tích đặc điểm phân bố các ĐVĐĐ và các loại LUS thấy rõ sự hình thành phân bố các LUS mang tính quy luật theo cấu trúc cảnh quan địa lý, khẳng định sự phù hợp trong tiếp cận xây dựng bản đồ LUS. Cần sử dụng đơn vị LUS làm đơn vị cơ bản đánh giá thích hợp đất đai và đánh giá kinh tế sinh thái các LUS.

Trong nghiên cứu này, kết quả bản đồ LUS huyện Phù Mỹ được xây dựng ở phân cấp loại
LUS, bản đồ LUS ở phân cấp phụ loại LUS là mục tiêu xây dựng để đánh giá LUS ở cấp xã, hợp tác xã hay cho một vùng canh tác cụ thể phục vụ cho quy hoạch SDĐ chi tiết. $\bigcirc$

\section{Tài liệu tham khảo}

[1]. Driessen P.M. (1997). Biophysical sustainability of land use systems. ITC-Journal (Netherlands).

[2]. Driessen P.M. and Konijn N.T. (1992), Land-use systems analysis, Wageningen Agricultural Univ, Wageningen.

[3]. (1994). Land use system evaluation: Concepts and methodology. Agricultural Systems, 44(3), 243-255.

[4]. Duivenbooden N. van (1997). Land Use Systems Analysis, a Multi-Scale Methodology to Explore Options for Development of Sustainable Agricultural Production Systems. Enschede, The Netherlands, 1-13.

[5]. Beek K.J., de Bie K., and Driessen P. Land information and land evaluation for land use planning and sustainable land management. 14.

[6]. A framework for land evaluation.

[7]. Tuấn T.V., Huần N.C., Thu Đ.T.T., et al. (2015). Nghiên cứu, đánh giá hệ thống sử dụng đất đai phục vụ quy hoạch sử dụng đất nông nghiệp bền vững (nghiên cứu điểm: xã Đại Thành, huyện Quốc Oai, thành phố Hà Nội). VNU Journal of Science: Earth and Environmental Sciences, 31(1).

[8]. Tai D.T.T. and Tuan T.V. (2017). Evaluation of Land Use System for Supporting Sustainable Development of Agriculture in Quoc Oai District, Hanoi City. VNU Journal of Science: Earth and Environmental Sciences, $33(4)$.

[9]. Nguyễn Trọng Đợi (2021) Mô hình đánh giá hiệu quả kinh tế-sinh thái phục vụ phát triển nông nghiệp bền vững trên cây lúa tại huyện Phù Mỹ, tỉnh Bình Định. Tạp chí KH\&CN Nhiệt đới, Số 21, trang 28-40.

(Xem tiếp trang 64) 